\title{
RELASI HABITUS \\ DALAM PERIKANAN NAPOLEON WRASSE DI KABUPATEN KEPULAUAN ANAMBAS, KEPULAUAN RIAU
}

\author{
Siti Arieta \\ Program Studi Sosiologi, Universitas Maritim Raja Ali Haji, Riau \\ arietasiti@umrah.ac.id
}

\begin{abstract}
This study examines fishery management on Napoleon wrasse species in Anambas Islands district from a sociological point of view, using agent-structure relations perspective proposed by Pierre Bourdieu. It is found that the vital values of this species (ecological economic, and social) are not applied equally. Expansionist relationship within the use of this species had caused economic value is more prioritized than others. As a result, sustainability of marine ecosystem becomes threatened. Other than that, fishing community as subsistence group is also ecologically in danger in a long term. Qualitative methodology was used for 8(eight) months period of time. This research was conducted at the center of Napoleon wrasse fishery within 3(three) sub districts consisting of 5(five) villages namely Air Sena (Siantan Tengah sub district), Batu belah (Siantan Timur sub district), also Putik, Ladan and Piabung (Palmatak sub district). Habitus formed by personal history and in addition to become a baseline for collective actions and commitment of involving actors has not been supporting the value of sustainable fisheries. This has caused incoherency between international and national commitment in protecting Napoleon wrasse. Thus, this habitus within the fishing communities and the network of Napoleon wrasse fishery considered to be a fallacy of thinking. Therefore, a governance is urgently needed in order to add the value knowledge, to change desires and habits in terms of supporting the establishment of sustainable Napoleon wrasse fishery in Anambas Islands district.
\end{abstract}

Keywords: habitus, doxa, value, Napoleon wrasse, sustainable 


\begin{abstract}
Abstrak
Penelitian ini melihat pengelolaan usaha perikanan Napoleon wrasse di Kabupaten Kepulauan Anambas, Provinsi Kepulauan Riau dari sudut pandang sosiologis dengan menggunakan perspektif relasi agen struktur yang dikemukakan oleh Pierre Bourdieu. Spesies Napoleon wrasse ditengarai memiliki 3 (tiga) nilai vital yakni nilai ekologis, ekonomis dan sosial. Namun sampai saat ini pemanfaatannya belum menerapkan ketiga nilai ini secara setara. Hal yang terjadi adalah ketidakberlanjutan ekosistem laut secara fisik dan terciptanya relasi ekspansionis yang secara ekonomis merugikan pihak subsisten yakni kelompok nelayan. Metode kualitatif digunakan dalam penelitian ini dalam kurun waktu 8(depalan) bulan. Lokus penelitian dilakukan pada sentra perikanan Napoleon wrasse yakni 3 (tiga) kecamatan yang terdiri dari 5 (lima) desa yakni Air Sena (kecamatan Siantan Tengah), desa Batu Belah (kecamatan Siantan Timur.), dan desa Putik, Ladan serta Piabung (kecamatan Palmatak) di Kabupaten Kepulauan Anambas. Habitus yang terbentuk akibat sejarah personal para aktor yang terlibat dalam perikanan Napoleon wrasse dapat dikatakan tidak mendukung nilai perikanan berkelanjutan. Akibatnya, habitus yang membentuk aksi kolektif dan komitmen dalam sistem nilai yang sama tidak sejalan dengan komitmen dunia internasional dan nasional untuk melindungi spesies Napoleon wrasse yang berstatus dilindungi dan terancam punah. Dengan demikian, relasi habitus yang terbentuk oleh para aktor yang terlibat dapat dikatakan sebagai sebuah fallacy of thinking sehingga diperlukan tata kelola untuk merubah pengetahuan, keinganan dan kebiasaan yang mendukung terciptanya perikanan Napoleon wrasse yang berkelanjutan.
\end{abstract}

Kata Kunci: habitus, doxa, nilai, Napoleon wrasse, berkelanjutan

\section{PENDAHULUAN}

Pengelolaan sumberdaya laut yang buruk telah menggambarkan kondisi chaotic yang mengancam kepunahan berbagai spesiessertadegradasi ekosistem laut (Longo \& Clausen, 2011; Pomeroy et al., 2016). Dijalankannya berbagai bentuk pengelolaan tetap tidak menghindarkan adanya relasi ekspansionis antara masyarakat dan lingkungan pesisir serta laut (Pitcher \& Lam, 2010).

Dalam merespon kondisi ini, ilmu sosiologi telah mengkaji persoalan relasi masyarakat dan lingkungan yang berakibat pada terjadinya degradasi lingkungan (Goldman \& Schurman, 2000).
Secarakonseptual,adopsikonsepmetabolic rift menjadi ocean metabolic rift telah menggambarkan ketidakseimbangan relasi antara manusia, masyarakat dan lingkungan laut yang menyebabkan retakan akibat pemanfaatan berlebih yang berdampak pada kelangkaan sumberdaya (Schnaiberg, 1980; Foster, 1999; Amarulia, O. \& Bayu A., 2014).

Untuk mengembalikan keretakan menjadi relasi yang seimbang, maka peran negara sangatlah dibutuhkan. Berbagai instrumen kebijakan untuk membatasi aktivitas penangkapan dan perdagangan, penetapan kawasan perlindungan guna mencegah degradasi laut yang lebih jauh, serta menetapkan 
status perlindungan berbagai spesies yang terancam punah merupakan wewenang pengelolaan berbasis negara (Hannesson, 1996; McKechnie, 2007). Namun, berbagai kebijakan yang ada ternyata belum menyelesaikan kompleksitas pengelolaan yang dihadapi sehingga dapat dikatakan peranan negara belum maksimal (Clausen \& Clark, 2005; Islam, 2017).

Sedangkan dari sudut pandang berbeda, pengelolaan laut berbasis masyarakat juga memiliki kelemahan yang dijelaskan oleh konsep tragedy of the commons (Hardin, 1968). Namun konsep ini menuai sanggahan karena masyarakat yang subsisten dengan alam melalui pengetahuan tradisionalnya diyakini tidak akan merusak sumber penghidupan mereka dan akan menjaga keberlanjutan melalui pengelolaan komunal (Stillman, 1975; Berkes, 1985; Ostrom, 1990; Berkes, 2012). Meskipun demikian, sangat disayangkan masih terdapatbuktiempiris yang menunjukkan bahwa pengelolaan komunal belum berjalan maksimal (Adhuri, 2013).

Oleh karena itu, kelemahan yang dimiliki baik oleh pengelolaan berbasis negara maupun komunal seyogyanya diantisipasi dengan membentuk kolaborasi. Adapun kolaborasi dapat dimaknai sebagai kebutuhan atas sistem pengelolaan laut yang dapat memaksimalkan sinergi yang dimiliki oleh masing-masing pihak yang terlibat (Pomeroy \& Berkes, 1997). Dilihat dari persepektif sosiologis, keterlibatan seluruh aktor yang terlibat akan mempengaruhi keberhasilan maupun kegagalan. Dalam penelitian ini, praktek pengelolaan laut dan sumberdaya perikanan didasarkan pada pemikiran
Pierre Bourdieu terkait relasi agen dan struktur dan hubungan dialektis antara keduanya.

Arena merupakan wadah kompetisi dimana berbagai modal (ekonomi, budaya, sosial dan simbolik) dan habitus digunakan dan disebarkan. Posisi aktor dalam masyarakat ditentukan oleh modal yang berperan dalam menentukan strategi untuk menjalankan praktek sosial (Jenkins, 1992; Adib, 2012). Dialektika yang terjadi antara habitus dan modal akan menimbulkan kemampuan aktor untuk merubah struktur sosial sesuai dengan kebutuhannya.

Gambaran arena pengelolaan laut dan sumberdaya perikanan sebagai dialektika habitus-modal inilah yang akan dijadikan objek penelitian. Adalah sebuah harapan penelitian ini akan berkontribusi dalam mewujudkan pengelolaan laut dan sumberdaya perikanan yang berkelanjutan.

Tantangan terbesar kolaborasi pengelolaan ini adalah keterhubungan berbagai aktor, jaringan, struktur dan sistem pengetahuan dalam tingkat kelola yang berbeda (Berkes, 2002; Carlsson \& Berkes, 2005; Folke et al., 2005; Ostrom, 2005; Armitage et al., 2008; Scarlett, 2013). Sinergi ini sangat dibutuhkan untuk menciptakan relasi yang mendukung upaya perlindungan, pelestarian dan keberlanjutan sumberdaya laut dan perikanan dalam menjawab ketidakmampuan daya dukungnya (jumlah dan kualitas) atas kehidupan manusia (Wilson, 1999; Buttel, 2002).

Peneliti terdahulu mengemukakan bahwa pengelolaan kolaborasi dipengaruhi oleh faktor eksternal yakni perubahan ekosistem, kebijakan, kondisi sosial politik dan kapasitas internal 
yang meliputi jejaring, organisasi dan individu, serta kemampuan adaptasi (Berkes, 2007; Plummer, 2009; Caves et al., 2013; Plummer et al., 2017). Fokus kajian tersebar di berbagai wilayah penerapan dengan tingkat keberhasilan yang berbeda-beda. Sejauhini, kajian terdahulu meliputi peranan kapasitas aktor dalam menghadapi dinamika tekanan internal maupun eksternal (Jentoft, 1989; Nielsen \& Vedsmand, 1997; Campbell et al., 2013), kepemimpinan dan proses pembelajaran sosial (McCay, 2002; Olsson et al., 2007; Evans et al., 2011), serta pentingnya kepercayaan diantara pihak yang terlibat (Guttierez et al., 2011; Crona \& Parker, 2012; Kowalski \& Jenkins, 2015; Ho et al., 2016).

Penelitian ini akan membahas dialektika relasi habitus dalam skema agen struktur. Pertimbangan ini didasari oleh asumsi bahwasanya pengelolaan yang inklusif menawarkan sebuah mekanisme yang lebih bertanggung jawab dalam pemanfaatan sumberdaya dan sensitif terhadap kondisi sosial ekonomi. Dengan demikian, rumusan masalah dalam penelitian ini adalah sebagai berikut: "Bagaimana relasi habitus yang terbentuk dalam perikanan Napoleon wrasse di Kepulauan Anambas?"

Gambaran relasi habitus ini diharapkan dapat menjadi pertimbangan intervensi untuk mencegah bertambah buruknya kondisi chaotic yang menyebagkan degradasi ekosistem karang dan dalam jangka panjang dapat kembali menyeimbangkan relasi ekspansionis antara masyarakat serta lingkungan pesisir dan laut.

\section{METODE}

Penelitian ini menggunakan metode kualitatif dengan dasar pertimbangan ingin diketahuinya permasalahan permasalahan dalam pengelolaan Napoleon wrasse secara komprehensif, dengan mengintegrasikan relasi struktur dan pola dalam perikanan Napoleon wrasse di Kepulauan Anambas. Penelitian kualitatif ini berupaya untuk menggali dan menelaah kondisi faktual dan menganalisnya dalam skema perikanan berkelanjutan. Adapun gambaran data yang dibutuhkan antara antara lain adalah kebiasaan yang membentuk pola struktur dalam perikanan Napoleon wrasse yang meliputi nilai, pengetahuan dan pengalaman para aktor yang terlibat. Selanjutnya, diperlukan gambaran atas kelas sosial yang terbentuk beserta komitmen dan upaya pelestarikan nilai yang diyakini.

Berdasarkan kebutuhan data yang disebutkan di atas, maka penelitian tentang relasi habitus dalam perikanan Napoleon wrasse dipandang sebagai fakta-fakta yang diobservasi yang akan menghasilkan pengetahuan yang didasarkan pada pengalaman, yaitu suatu konsep baru yang disusun berdasarkan temuan penelitian.

\section{III.HASIL DAN \\ PEMBAHASAN}

Dalam ekosistem laut, spesies ikan karang memiliki nilai jual yang tinggi termasuk spesies Napoleon wrasse yang saat ini telah ditetapkan menjadi spesies rawan punah menurut International Union for Conservation of Nature pada tahun 2004 dan berstatus perlindungan 
terancam oleh Lampiran II CITES pada tahun 2005 (CITES, 2004; Gillet, 2010). Artinya, spesies ini tetap boleh diperdagangkan namun dalam batas ukuran tertentu. Hal ini menarik untuk diteliti mengingat diantara spesies ikan karang yang diperdagangkan hidup (Live Reef Fish Trade-LRFT), hanyalah Napoleon wrasse yang berstatus demikian sehingga spesies ini memiliki nilai tinggi dalam perdagangan.

Di Indonesia, keberadaan spesies Napoleon wrasse di perairan Indonesia tersebar di wilayah Kepulauan Riau, Bali, Raja Ampat, Bunaken, Banda dan Nusa Tenggara Timur. Dari seluruh lokasi yang memiliki potensi ikan napoleon di Indonesia, hanya Kabupaten Kepulauan Anambas yang memiliki stok berlimpah di keramba dan siap ekspor untuk memenuhi permintaan pasar.

Sejak tahun 2014, sebagian wilayah Kabupaten Kepulauan Anambas telah ditetapkan menjadi Kawasan Konservasi Perairan Nasional (KKPN) berdasarkan Keputusan Menteri Kelautan dan Perikanan No. 37 tahun 2014, yang memiliki konsekuensi terjaminnya keberlanjutan kualitas habitat dan sumberdaya perikanan. Secara umum, tekanan penangkapan yang berlebihan terhadap sumberdaya ikan di sekitar kawasan konservasi dan kondisi ekosistem karang yang kurang baik merupakan gambaran konservasi di perairan Anambas (Mustika et al., 2013.). Namun secara khusus, penetapan Kawasan Konservasi Perairan Nasional ini belum menjamin keberlanjutan spesies Napoleon wrasse di perairan Anambas.

Memiliki potensi sumberdaya laut yang melimpah telah menjadikan masyarakat Kabupaten Kepulauan
Anambas bekerja di sektor pesisir dan laut. Profesi nelayan tangkap terklasifikasi menjadi nelayan laut lepas dengan durasi 3-7 hari waktu melaut, dan nelayan pesisir yang aktivitasnya di sekitaran tempat tinggal. Klasifikasi tersebut juga membedakan hasil tangkapan nelayan, dimana nelayan laut lepas menjadikan ikan berukuran besar sebagai objek tangkapan. Sedangkan nelayan pesisir lebih fleksibel mengingat alat yang dipakai adalah bubu yang ditancapkan pada dasar laut dangkal, ataupun mengambil langsung spesies seperti kerang, cumi-cumi, kepiting dan lainnya. Nelayan pesisir juga kerap melakukan budidaya pembesaran spesies ikan karang maupun rumput laut.

Namun, dalam konteks sejarah, baik nelayan laut lepas dan pesisir melakukan aktivitas pengeboman ikan yang sangat masif sehingga kondisi terumbu karang di wilayah perairan ini rusak. Hal ini dimaksudkan agar aktivitas penangkapan lebih mudah. Meskipun saaat ini pengobaman ikan tidak lagi dilakukan karena pengawasan dan hukuman telah diterapkan, namun sistem nilai yang terbentuk tidak sejalan dengan nilai keberlanjutan. Nilai yang diyakini ini menjadi dasar motivasi bagi setiap tindakan yang dilakukan.

Dalam perikanan Napoleon wrasse, aktivitas pemanfaatan terbagi ke dalam beberapa periode. Periode awal, saat spesies dengan ukuran 1 kilogram ke atas masih banyak terdapat di laut, bom kerap digunakan saat spesies ini ditangkap bersamaan dengan ikan karang lainnya meskipun penggunaaan jaring juga dilakukan. Periode selanjutnya yakni penggunaan sianida yang disemprotkan ke karang, merupakan praktek yang 


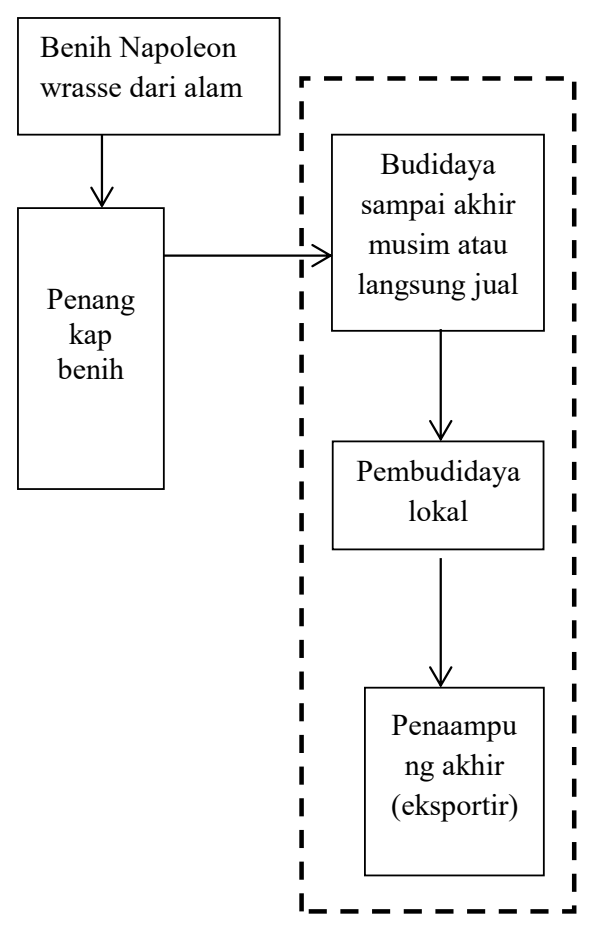

\section{Gambar 1. Jaringan Budidaya Napoleon wrasse}

tidak berkelanjutan yang dilakukan setelah pengeboman berakhir. Didasari motif yang sama, penggunaan sianida ini juga mengatasnamakan efisiensi dalam menangkap spesies ikan karang yang memiliki nilai jual yang tinggi sampai saat ini.

Praktek yang dilakukan dalam kedua periode ini telah membawa konsekuensi terhadap stok spesies Napoleon wrasse berukuran besar, dimana keberadaan mereka tidak lagi terlihat. Namun hal ini tidak berarti penangkapan Napoleon wrasse berakhir, saat ini penangkapan yang dilakukan adalah dengan menangkap benih anakan Napoleon wrasse yang berukuran sebesar biji beras. Dalam konteks penangkapan, hal ini tentunya lebih mudah karena keberadaan benih ini bukan lagi pada ekosistem karang, namun saat musim sargassum memenuhi laut dangkal pada periode bulan September sampai dengan Januari setiap tahunnya. Namun praktek ini juga tidak sesuai dengan aturan tangkap yang diamanatkan oleh aturan internasional dan nasional, dimana ukuran minimal tangkap adalah 1 inchi.

Ketersediaan stok Napoleon wrasse yang langka di alam menjadikan ranching atau budidaya sebagai upaya untuk memenuhi permintaan pasar yang telah berlangsung sejak tahun 1980-an. dimana dalam kurun waktu tersebut dominasi praktek yang dilakukan adalah penangkapan dalam kedua periode yang dijelaskan di atas. Sedangkan status dilindungi dan terancam punah memiliki konsekuensi yang wajib diterapkan dalam perdagangan. Untuk mencapai berat minimal yang diizinkan untuk dijual yakni 1(satu) kilogram, dibutuhkan waktu 4-5 tahun (Soemodinoto et al., 2013). Hal ini menandakan dibutuhkannya modal yang besar untuk keperluan pakan dan pemeliharannya, yang juga dapat diartikan hanya aktor tertentu yang dapat melakukan budidaya Napoleon wrasse.

Dalam hal ini pemilik modal tidak bekerja sendiri, akan tetapi membangun jejaring dalam melaksanakan usaha perikanan Napoleon wrasse. Jaringan yang dibuat adalah dengan bekerja sama dengan pihak nelayan, pihak penampung serta jalur distribusi internasional dimana sampai saat ini negara pengimpor tunggal Napoleon wrasse adalah Hongkong (Sadovy \& Suharti, 2008; Dirhamsyah, 2014).

Jaringan dalam praktek budidaya Napoleon wrasse menjadi sumber mata pencaharian. Saat sargassum atau yang dalam istilah lokal dikenal sebagai 
kerkam yang muncul setiap bulan September hingga Januari setiap tahunnya, mayoritas masyarakat di Kabupaten Kepulauan Anambas ikut berpartisipasi dalam menangkap benih Napoleon wrasse. Bukan hanya nelayan, namun mulai anak-anak usia sekolah dasar yang telah pandai berenang pun turut serta. Namun tidak semua benih yang berhasil ditangkap adalah Napoleon wrasse, karena sargassum merupakan tempat berbagai spesies ikan bertelur sehingga beribu benih yang menetas hampir tidak bisa dibedakan. Terlebih bagi mereka yang bukan berprofesi sebagai nelayan, seringkali benih yang tertangkap bukanlah Napoleon wrasse atau yang dikenal sebagai ikan ketipas menurut masyarakat lokal.

Selain nelayan tangkap yang melakukan aktivitas penangkapan benih, aktor lain yang terlibat adalah para penampung baik penampung lokal dan penampung akhir, yakni yang menjalin relasi dengan pasar Hongkong dan melakukan aktivitas ekspor. Meskipun terdapat perbedaan tingkatan stratifikasi ekonomi dari para aktor yang terlibat, namun dari sistem nilai dapat dikatakan mereka memiliki habitus yang sama. Dalam konteks relasi agen-struktur yang dikemukakan oleh Pierre Bourdieu, sistem nilai yang dimiliki oleh aktor dapat dikatakan terbentuk melalui sejarah personal (Jenkins, 2004). Keseluruhan nilai, pengetahuan dan pengalaman ini merupakan bentuk habitus dari para aktor yang terlibat dalam perikanan Napoloen wrasse.

Konsep habitus berusaha menyatukan dualitas struktur dan aktor, dan pendekatan ini disebut sebagai strukturalisme genetis. Habitus dapat menyebabkan dominasi dari dalam, dimana sebelumnya dominasi kerap dianggap terjadi oleh faktor luar. Habitus memungkinkan aktor untuk memahami struktur sosial yang tidak selalu memiliki cara kerja yang sama pada setiap aktor. Asumsi inilah yang membangun teori reproduksi sosial dan logika atas tindakan, yang menggambarkan kondisi berfungsinya masyarakat.

Habitus yang membentuk struktur kelas sosial yang dimaksudkan dalam pembentukan aksi kolektif yang akan terwujud dalam kelompok habitus yang sama (Adib, 2012). Adanya aktor dominan dalam setiap kelas sosial akan menerapkan strategi dominasi yang dapat menggerakkan tindakan kolektif. Dalam konteks perikanan Napoleon wrasse, sangat jelas gambaran relasi timbal balik dari habitus yang membentuk kelas sosial, dan kelas sosial yang melanggengkan nilai yang dianut dalam konteks penangkapan benih Napoleon wrasse.

Hal ini dapat dilihat dari periode penangkapan benih yang dilakukan sampai saat ini dapat dikatakan mencerminkan nilai yang tidak berkelanjutan. Sepanjang spesies ini memiliki harga, para nelayan tidak sungkan melanggar aturan minimal tangkap karena benih Napoleon wrasse tersedia dianggap sangat banyak. Tidak diperlukan pengorbanan yang besar dari sisi tenaga dan modal ekonomi untuk menangkapnya.

Langgengnya pola yang menjadi kebiasaan ini merupakan tuntutan pemilik modal yang memiliki akses terhadap pasar yang menyebabkan rantai jaringan yang tidak pernah putus dalam memenuhi kebutuhan pemilik modal yang secara langsung 
memberikan keuntungan bagi mereka yang berpartisipasi dalam perikanan Napoleon wrasse. Dari sudut pandang penangkap benih, keuntungan tidak dihitung berdasarkan besar ataupun kecil namun partisipasi yang dilakukan akan membuka akses terhadap aktor dominan yakni penampung lokal maupun eksportir dan membawa prestise yang cukup tinggi.

Kesadaran semu yang dimiliki oleh penangkap benih dalam dinyatakan sebagai sebuah ketidaksetaraan jaringan. Analisis ekonomi yang dilakukan oleh Soemodinoto et al. (2013) membuktikan bahwa keuntungan yang diperoleh dari budaya Napoleon wrasse hanya akan diperoleh oleh pembudidaya penuh, yang dimaksudkan sebagai pembudidaya yang melakukan ranching hingga ukuran minimal untuk dijual yaitu 1 (satu) kilogram.

Tabel 1. Analisis Finansial Sederhana Tiga Macam Budidaya Napoleon wrasse di Kabupaten Kepulauan Anambas

\begin{tabular}{|l|l|r|r|c|}
\hline No & \multicolumn{1}{|c|}{ Kategori } & $\begin{array}{c}\text { Pembesaran } \\
\text { Benih -3 } \\
\text { bulan (Rp) }\end{array}$ & $\begin{array}{c}\text { Pembesaran } \\
\text { Ikan Muda } \\
-\mathbf{1} \text { tahun } \\
\text { (Rp) }\end{array}$ & $\begin{array}{c}\text { Pembesaran } \\
\text { Penuh - 4 } \\
\text { sampai 5 } \\
\text { tahun (Rp) }\end{array}$ \\
\hline 1 & Investasi & $2,925,000$ & $31,750,000$ & $31,750,000$ \\
\hline 2 & $\begin{array}{l}\text { Biaya Tidak } \\
\text { Tetap }\end{array}$ & $15,821,250$ & $96,355,000$ & $271,195,000$ \\
\hline 3 & $\begin{array}{l}\text { Biaya total } \\
(1+2)\end{array}$ & $18,746,250$ & $128,105,000$ & $302,945,000$ \\
\hline 4 & $\begin{array}{l}\text { Pendapatan } \\
\text { kotor }\end{array}$ & $12,500,000$ & $128,105,000$ & $302,945,000$ \\
\hline 5 & $\begin{array}{l}\text { Keuntungan } \\
(4-3)\end{array}$ & $-6,246,250$ & $-8,105,000$ & $177,055,000$ \\
\hline
\end{tabular}

Sumber: Soemodinoto et al., 2013

Tabel di atas menyiratkan bahwasanya terdapat manfaat ekonomi hanya dirasakan oleh kelompok tertentu. Perolehan nilai jual tangkap langsung dalam jangka pendek memang dinilai menghasilkan, namun kerugian yang diabaikan adalah dalam konteks jangkap panjang. Keuntungan pemilik modal yang mampu melakukan budidaya penuh yakni 4-5 tahun merupakan akibat adanya rantai pasokan benih yang ditangkap. Dengan demikian, relasi yang terbentuk dalam jaringan perdagangan Napoleon telah menggambarkan sebuah hubungan yang tidak setara antara penangkap dan penampung.

Namun, para aktor yang terlibat langsung dalam perikananNapoleonwrasse tidak berpendapat demikian. Orientasi nilai ekonomis tetap merupakan dasar anggapan, dimana slogan 'justru dengan menangkap benih, kami menyelamatkan mereka dari predator dan menjamin jumlah hidup yang lebih banyak'. Hal ini merupakan dampak atas pengalaman moratorium tangkap benih Napoloen wrasse yakni berupa kesepakatan seluruh desa di Kabupaten Kepulauan Anambas pada tahun 2012. Namun saat moratorium berakhir dan aktivitas kembali dilakukan di tahun 2013, mereka membuktikan bahwasanya jumlah tangkapan benih sangat jauh berkurang dibandingkan dengan tanpa adanya moratorium. Maka, mereka meyakini bahwa semakin rendah aktivitas penangkapan benih Napoleon wrasse, maka jumlah benih di alam akan semakin sedikit.

Justifikasi ini tidak dapat dibenarkan dan dapat dikategorikan sebagai fallacy of thinking, karena dalam kurun waktu moratorium tidak disertai oleh pengawasan bersama dan penerapan mekanisme sanksi atas kesepakatan tersebut. Bukan tidak mungkin, aktivitas penangkapan benih tetap dilakukan namun secara sembunyi-sembunyi. 
Permasalahan yang dihadapi dalam pemanfaatan Napoleon wrasse yang memiliki nilai vital dalam ekosistem tidak didukung oleh pola kebiasaan masyarakat di Kabupaten Kepulauan Anambas. Hal ini menandakan minimnya komitmen lokal dalam upaya perlindungan atas keberlanjutan spesies ini. Sedangkan pada tingkatan internasional dan nasional terdapat upaya berkelanjutan dan pada konteks daerah, masyarakat dituntut untuk melakukan praktek yang mendukung semangat keberlanjutan tersebut.

Dilihat dari perspektif Bourdieu, internalisasi pengalamanakan diwariskan kepada generasi penerus secara alamiah. Akibatnya, generasi tersebut akan memiliki penilaian yang sama meskipun tidak mengalami pengalaman yang sama dengan generasi sebelumnya. Inilah yang disebut dengan structuring structure (Jenkins, 2004). Konsistensi ini dapat terwujud jika terdapat manifestasi habitus para aktor masyarakat yang memiliki status sosial yang dihormati. Aktor dengan kekuasaannya dapat membentuk sebuah tatanan sosial dalam individu yang terikat pada tradisi, yang memiliki kekuasaan alami dalam membentuk habitus masyarakat. Hal ini disebut dengan istilah doxa.

Relasi habitus yang dilihat dari nilai, pengetahuan dan pengalaman yang membentuk kelas sosial dan komitmen dalam perikanan Napoleon wrasse secara jelas memperlihatkan nilai yang telah melalui proses structuring structure, dimana aktor dominan juga telah berhasil membentuk doxa. Namun sangat disayangkan ketika seluruh proses ini membentuk sebuah komitmen yang tidak mendukung keberlanjutan ekosistem laut. Ditambah lagi, terdapat perbedaan persepsi antara pembuat aturan dan para aktor yang terlibat dalam perikanan Napoleon wrasse.

Larangan untuk menangkap benih dibawah ukuran 1 inchi disertai dengan pertimbangan pertumbuhan spesies ini secara alami. Diakui bahwasanya benih Napoleon wrasse memiliki tingkat bertahan hidup yang rendah akibat adanya spesies predator. Pihak pembuat kebijakan beranggapan bahwa dengan membiarkan spesies ini tumbuh secara alami berapapun jumlahnya, populasi tersebut tidak akan seluruhnya dapat ditangkap oleh nelayan. Hal ini merupakan dasar penilaian keberlanjutan, karena spesies yang tidak tertangkap akan tumbuh alami sehingga akan tercipta upaya mengembalikan stok alami Napoleon wrasse di laut.

Namun hal ini belum dapat tersinkronisasi dengan pihak pengguna sumberdaya Napoleon wrasse di Kabupaten Kepulauan Anambas. Ketidaksinkronan upaya keberlanjutan spesies Napoleon wrasse ini juga didukung oleh ketidaksiapan pemerintah daerah. Hal ini terjadi akibat adanya pemindahan wewenang pengelolaan laut yang sebelumnya berada pada pemerintah kabupaten, dan saat ini merupakan wewenang pemerintah provinsi sesuai dengan perubahan Undangundang nomor 24 tahun 2014 tentang Pemerintahan Daerah.

Tekanan pihak internasional atas perlindungan spesies Napoleon wrasse merupakan gambaran evolusi paradigma pembangunan perikanan. Proses ini diawali dengan paradigma konservasi (biologi), rasionalisasi (ekonomi) dan saat ini telah bergeser ke arah paradigma 
sosial (komunitas) yang ketiganya masih relevan untuk digunakan untuk dijadikan paradigma perikanan berkelanjutan (Charles, 1994).

Adapun konsep pembangunan perikanan berkelanjutan mengandung aspek keberlanjutan ekologi, keberlanjutan sosial ekonomi, keberlanjutan komunitas, serta keberlanjutan institusional. Keberlanjutan ekologi memandang pentingnya memelihara keberlanjutan stok agar tidak melewati daya dukung yang disertai upaya meningkatkan kapasitas dan kualitas dari ekosistem. Keberlanjutan sosial ekonomi merupakan sebuah konsep yang mendasarkan pembangunan perikanan yang memperhatikan keberlanjutan dari kesejahteraan pelaku perikanan dimana tingkatan individu tidak dikecualikan. Selanjutnya, keberlanjutan komunitas mengandung makna bahwa komunitas sebagai satuan masyarakat terkecil haruslah menjadi perhatian karena praktek memanfaatkan sumberdaya didasarkan pada kearifan tradisional.

Ketiga aspek keberlanjutan ini dapat tercipta jika terdapat keberlanjutan institusional, yang bermakna sebagai pemeliharaan aspek finansial dan administrasi yang sehat. Dengan demikian setiap dimensi haruslah dijadikan komponen penting yang dipadukan sebagai sistem yang inklusif, yang ditujukan untuk melahirkan kebijakan mewujudkan perikanan berkelanjutan.

Proses evolusi yang dimulai sekitar tahun 1990 merupakan respon akibat seruan Rio Summit, dimana perbaikan secara global terhadap pengelolaan sumberdaya alam menjadi kebutuhan yang mendesak. Dalam konteks laut dan perikanan, fenomena collapse nya stok spesies anchovy, tuna dan salmon serta berbagai spesies lain yang menjadi berstatus terancam punah telah menyadarkan timbulnya konsekuensi sosial ekonomi selain dari hanya konsekuensi ekologis, dominasi kekuatan dari pemangku kepentingan yang terlibat telah menyebabkan degradasi lingkungan laut akibat ketamakan para aktor.

Harapannya, evolusi yang pembangunan perikanan berkelanjutan dapat menciptakan perikanan yang bertanggung jawab dalam menyikapi degradasi lingkungan laut, over eksploitasi dan praktek penangkapan yang merusak. Dengan adanya perkembangan ini, adalah sebuah harapan besar agar para pemangku kepentingan secara inklusif beritikad untuk mewujudkan pembangunan perikanan berkelanjutan.

Namun dilihat dari relasi habitus dalam perikanan Napoleon wrasse di Kabupaten Kepulauan Anambas, mewujudkan perikanan yang berkelanjutan hampir mustahil untuk dilakukan jika dilihat dari perspektif Bourdieu. Dibutuhkan intervensi kekuatan yang lebih kuat untuk merubah doxa yang telah terbentuk. Sebagai pihak yang juga diharapkan berpartisipasi dalam menemukan solusi dalam permasalahan ini, pemerintah diharapkan menerapkan sistem tata kelola dalam membentuk perikanan Napoleon wrasse yang berkelanjutan.

Tata kelola secara umum dimaknai sebagai sebuah aktivitas manajerial harian ketimbang struktur pembuatan keputusan maupun sistem 
administratif (Ostrom, 1990). Tata kelola mengamanatkan kebutuhan atas analisa kebijakan institusional yang dapat tercipta melalui beberapa tahapan. Pertama ialah tahapan instruktif dan konsultatif, dimana pertukaran informasi antara pemerintah dan pihak pengguna sumberdaya sangat minim namun terdapat itikad untuk melakukan dialog dan konsultasi meski pemerintah cenderung menjadi pemegang keputusan.

Selanjutnya adalah tata kelola sebagai tahapan kooperatif, adalah ketika pemerintah dan pengguna sumberdaya mampu bekerja sama dan menjadi mitra yang setara dalam pembuatan keputusan. Ketiga adalah tata kelola sebagai tahapan pemberian nasihat, diartikan sebagai kelompok pengguna sumberdaya yang memiliki kemampuan menjadi penasihat pemerintah dalam membuat keputusan, dan pemerintah hanya bertindak untuk mengesahkan keputusan. Tahapan terakhir adalah informatif yakni pemerintah yang telah mendelegasikan kewenangan untuk membuat keputusan kepada pengguna sumberdaya (Sen \& Nielsen, 1996).

Tata kelola menekankan pentingnya kondisi kontekstual dalam mencapai kesuksesan pengelolaan sumberdaya alam, yang antara lain meliputi ukuran dari sumberdaya dan tingkat kebergantungannya dilihat dari faktor demografis, tingkatan modal sosial serta kehadiran dan tingkatan konflik. Konflik dapat terjadi antara sistem kepemilikan bersama dan anggotanya. Intensitas dan frekuensi konflik biasanya terjadi dikaitkan dengan persepsi kelangkaan relatif atas sumberdaya. Bagian dari proses institusional harus melibatkan mekanisme diskusi dan penyelesaian atas pelanggaran aturan dan perselisihan baik secara formal dan informal. Secara umum, untuk membentuk efektifitas sanksi nelayan harus terlibat dalam proses institusionalisasi, pengawasan dan implementasi.

Lapisan aturan dalam tata kelola yang akan membentuk institusi. Aturan konstitusional memberikan rincian atas syarat dan kondisi tata kelola. Aturan jenis ini menetapkan siapa yang memiliki hak dalam memutuskan terkait akses dan penggunaan sumberdaya juga siapa yang berhak untuk mendistribusikan keuntungan. Adapun aturan pilihan kolektif merupakan mekanisme pembuatan keputusan, sedangkan aturan operasional adalah untuk keseharian. Ketiga lapisan aturan ini akan membentuk hierarki dimana aturan yang lebih tinggi akan menentukan tingkat kebebasan aturan dibawahnya.

Keputusan konstitusional akan menjadikan pengaturan institusional dan penerapannya guna membentuk pilihan kolektif. Sebaliknya, pilihan kolektif yang menaungi keduajenis aturan lainnya akan menentukan pengaturan institusional guna membentuk aksi individu. Pilihan konstitusional mendahului dan memaksa pilihan kolektif. Hal ini mengartikan bahwasanya tingkatan konstitusional dimengerti sebagai sistem aturan yang merinci syarat dan kondisi dari tata kelola, dimana tata kelola itu sendiri termasuk aturan, aplikasi, dan mekanisme peradilannya. Meskipun dapat dilihat dari aktivitas harian dimana aturan operasional dijadikan panduan.

Sistem tata kelola bermakna sebagai koordinasi dan adaptasi terhadap sistem sosial dan lingkungan dapat dijalankan melalui 2 (dua) pendekatan. Pendekatan 
pertama yakni berbasis negara dilakukan dengan mempertanyakan kapasitas institusi dan politik negara dalam mengatur perannya dan menjembatani kepentingan aktor berpengaruh lainnya dalamsistem pengelolaanyangdilakukan. Sedangkan pendekatan kedua adalah berbasis masyarakat yang berfokus pada koordinasi dan pengelolaan mandiri yang dimanifestasikan melalui berbagai jenis jejaring dan kemitraan (Pierre \& Peters, 2000). bernilai secara ekonomis. Adapun modal kultural merupakan pengetahuan yang diperoleh, kode-kode budaya, etika yang berperan dalam penentuan dan reproduksi kedudukan-kedudukan sosial. Modal kultural menjadi sebuah nilai tambah bagi kekuatan aktor untuk menjembatani tujuan dengan mengintegrasikan perspektif lokal serta merevitalisasi budaya lokal dalam setiap

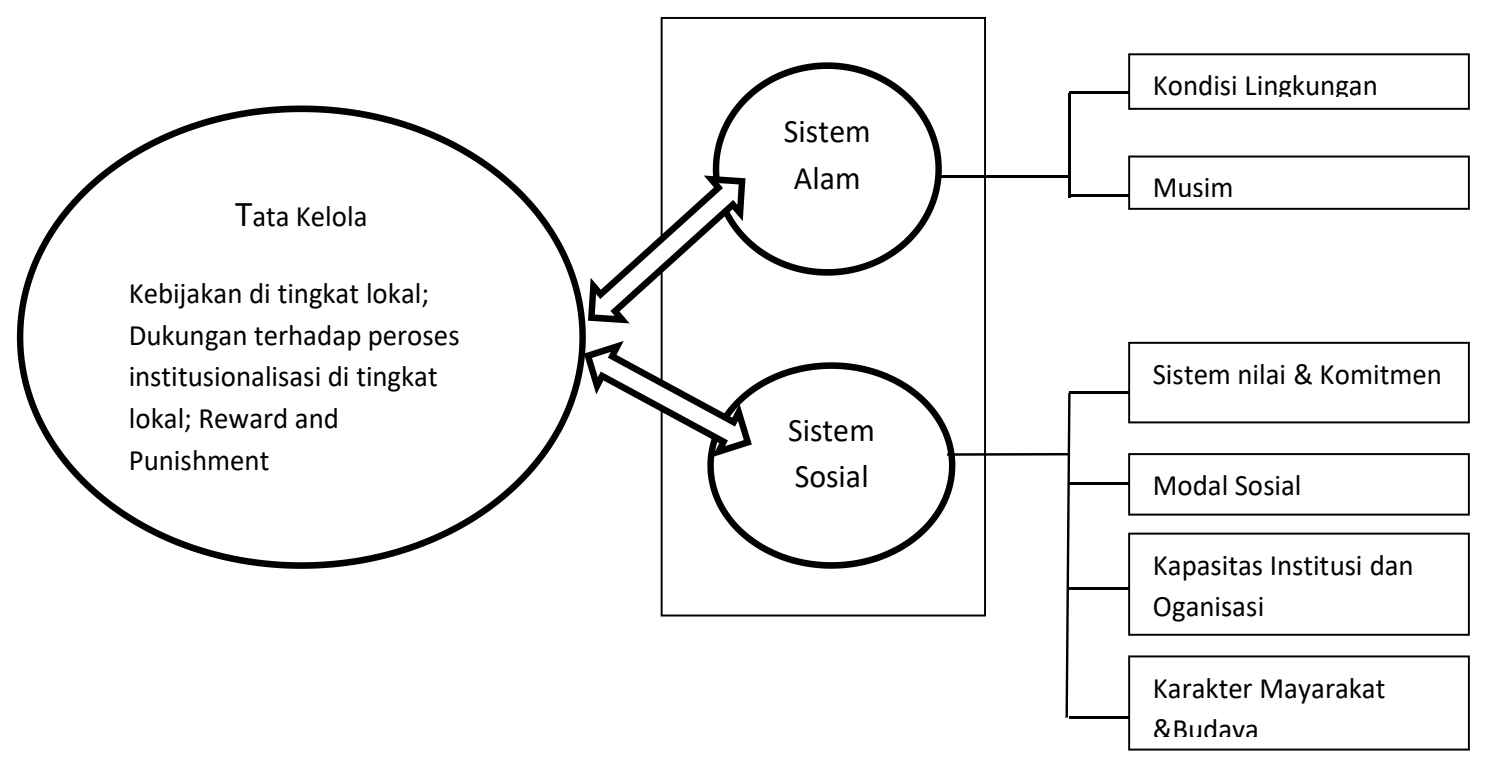

Dalam masyarakat yang terdeferensiasi, terdapat yang menguasi dan dikuasai. Menurut Bourdieu, kekuasaan merupakan gambaran dari kepemilikan modal yang dominan dalam sebuah arena. Modal merupakan konsentrasi kekuatan spesifik yang beroperasi dalam ranah atau kemampuan yang dimiliki aktor yang digunakan untuk mempertahankan eksistensinya, dan mengendalikan orang lain. Modal terdiri dari modal ekonomi, modal sosial, modal kultural maupun modal simbolik.

Modal ekonomi dapat dilihat dari dominasi kepemilikan asset yang implementasi kekuatan. Sedangkan modal sosial akan sangat menentukan reproduksi kedudukan sosial karena proses ini melibatkan jaringan yang dibentuk oleh rasa percaya antara agenagen yang terlibat yang akan membawa hubungan yang saling menguntungkan. Pada akhirnya, akumulasi modal akan melahirkan modal simbolik yang paling bernilai secara politis. Modal simbolik merupakan legitimasi kuasa yang terkemas di dalam simbol-simbol, yang berperan untuk memapankan kekuasaan serta memperoleh kesetaraan dengan apa yang diperoleh melalui kekuasaan fisik 
dan ekonomi berkat adanya mobilisasi (McNay, 1999).

Akumulasi modal dalam perikanan Napoleon wrasse di Kabupaten Kepulauan Anambas berada pada aktor dominan yang berhasil membentuk doxa dan melestarikan struktur nilai secara turun temurun, seperti yang telah dijelaskan sebelumnya. Namun persepsi negatif yang menghalangi terwujudnya kondisi berkelanjutan membutuhkan intervensi tata kelola yang digambarkan sebagai berikut:

Diharapkan, tata kelola yang diterapkan sebagai sebuah kerjasama dalam pengelolaan perikanan Napoleon wrasse dapat merubah fallacy of thinking akibar relasi habitus yang dimiliki oleh para aktor pengguna sumberdaya spesies ini. Dengan demikian, relasi ekspansionis para aktor yang terlibat dapat dirubah seiring dengan proses jangka pendek, jangka menengah dan jangka panjang.

\section{IV.SIMPULAN}

Berdasarkan uraian di atas, hal yang patut digarisbawahi dari pemanfaatan spesies Napoleon wrasse yakni terdapat nilai ekologis yang diabaikan demi kepentingan ekonomi. Hal ini juga akan berdampak pada nilai sosial dalam jangka panjang, yakni ketika ketidakseimbangan ekosistem yang terjadi akan merugikan pihak-pihak yang subsisten. Degradasi lingkungan laut dan sumberdaya perikanan akan berpengaruh langsung terhadap keberlanjutan kehidupan kelompok nelayan.

Tata kelola dalam bentuk kolaborasi pengelolaan menjadi sebuah kebutuhan sebagai bentuk intervensi pemerintah pusat terhadap pemerintah provinsi dan kabupaten, yang diharapkan juga membangun kapasitas kelompok pengguna sumberdaya spesies Napoleon wrasse untuk memiliki visi berkelanjutan.

\section{UCAPAN TERIMA KASIH}

Penelitian ini merupakan bagian dari skema Penelitian Disertasi Doktor yang berjudul Relasi Sosial dalam Pengelolaan Napoleon wrasse yang Berkelanjutan di Kabupaten Kepulauan Anambas, yang didukung oleh Lembaga Penelitian Pengabdian Masyarakat dan Penjaminan Mutu (LP3M) Universitas Maritim Raja Ali Haji, Tanjungpinang-Kepulauan Riau.

\section{DAFTAR PUSTAKA}

Adhuri, D. 2013. Selling the Sea, Fishing for Power: A study of conflict over marine tenure in Kei Islands, Eastern Indonesia. Canberra: ANU Press.

Adib, M. 2012. Agen dan Struktur dalam Pandangan Piere Bourdieu. BioKultur, Vol.I/No.2/Juli-Desember 2112, 91-110.

Armitage et al. 2008. Adaptive comanagement and paradox of learning. Global Environmental Change, 86-98.

Berkes, F. 1985. Fishermen and 'The Tragedy of the Commons'. Environmental Conservation, Vol. 12, No.3, 199-206.

Berkes, F. 2002. Cross scale institutional linkages: Perspective from the bottom up. In e. Ostrom et al, The Drama of the Commons (pp. 291-321). Washington, DC: National Academy Press.

Berkes, F. 2007. Adaptive co-management and complexity: exploring the many faces of co-management. In F. B. D. Armitge, Adaptive co-management: collaboration, learning and multi-level governance (pp. 19-38). Vancouver, British Columbia, Canada: University of British Columbia Press.

Berkes, F. 2012. Sacred Ecology, 3rd edition. 
New York: Routledge.

Buttel. 2002. Environmental Sociology and the Sociology of Natural Resources: Institutional Histories and Intellectual Legacies. Society and Natural Resources, 15, 205-211.

Campbell et al. 2013. Co-management: approaches and incentives improve management. Marine Policy 41, 72-79.

Carlsson \& Berkes. 2005. Co-management: concepts and methodological implications. Journal of Environmental Management, 65-76.

Cavesetal.2013.IntegratingCollaboration, Adaptive Management, and ScenarioPlanning Experiences at Las Cienegas National Conservation Area. Ecology and Society, Vol. 18, No. 3.

Charles, A. 1994. Towards sustainability: The Fishery Experience. Ecological Economics (11), 201-211.

Clausen, R. \& Clark, B. 2005. The metabolic rift and marine ecology: An analysis of ocean crisis within capitalist production. Organization $\mathcal{E}$ Environment 18, 422-444.

Crona, B.I. \& Parker, J.N. 2012. Learning in Support of Governance Theories, Methods, and a Framework to Assess How Bridging Organizations Contribute to Adaptive Resource Governance. Ecology and Society, Vol. 17, No. 1.

Dirhamsyah. 2014. IUU fishing in Indonesia's live reef fisheries. Australian Journal of Maritime \& Ocean Affairs, 44-52.

Evans et al. 2011. Assessing the impact of fisheries co-management interventions in developing countries: A meta-analysis. Journal of Environmental Management 92 , 19381949.

Folke, et al. 2005. Adaptive governance of social-ecological systems. Annu Rev Environ Resour 30, pp. 441-473.

Foster, T. 2013. Predictors of sustainability for community-managed handpumps in sub-Saharan Africa: Evidence from Liberia, Sierra Leone and Uganda. Environmental Science \& Technology, 12037-12046.

Goldman \& Schurman. 2000. Closing the Great Dive: New Social Theory on Society and Nature. Annual Review of Sociology Vol.26, 563-584.

Guttierez et al. 2011. Leadership, social capital and incentives promote succesful fisheries. Nature Vol. 470, 386-389.

Hannesson, R. 1996. Fisheries mismanagement: the case of the North Atlantic cod. Oxford: Fishing New Books Ltd.

Hardin, G. 1968. The tragedy of the commons. Sceience 162, 1243-1248.

Ho et al. 2016. The Influence of Leadership in Fisheries Co-Management: the Case of Tam Giang Lagoon Vietnam. Society \& Natural Resources, 1-16.

Islam, M. 2017. Sustainability through the Lens of Environmental Sociology: An Introduction. Sustainability.

Jenkins, R. 2004. Membaca Pikiran Pierre Bourdieu (Terjemahan Nurhadi). Yogyakarta: Kreasi Wacana.

Jentoft, S. 1989. Fisheries co management: Delegating government responsibility to fishermen's organizations. Marine Policy, 137-154.

Kowalski \& Jenkins. 2015. The Role of Bridging Organizations in Environmental Management: Examining Social Networks in Working Group. Ecology and Society, Vol. 20, No. 2 (Jun 2015).

Longo \& Clausen. 2011. The Tragedy of the Commodity: The overexploitation of the Mediterrian blue fin tuna. Organization \& Environment 24(3), 312-328.

McCay, B. 2002. Emergence of institutions for the commons: contexts, situations, and events. In N. D. E.T. Diez, The drama of the commons (pp. 361-402). 
Washington, D.C., USA: National Academy Press.

McKechie, I. 2007. Investigating the complexities of sustainable fishing at a prehistoric village on western Vancouver Island, British Columbia, Canada. . Journal for Nature Conservation Vol 15(3), 208-222.

Mustika, P. L., Gunawan, T. \& Erdmann, M. V. (eds). 2013. A Marine Rapid Assessment (MRAP) of the Anambas Islands Marine Tourism Park, 3-31 May 2012. Ministry of Marine Affairs and Fisheries, Indonesian Institute of Science (LIPI), the Government of Anambas Regency, The Nature Conservancy, Conservation International Indonesia, The Nature Conservancy. Denpasar: Conservation International Indonesia.

Nielsen and Vedsman. 1997. Fishermen's organization in fisheries management: Perspective for fisheries co management based on Danish fisheries. Marine Policy, Vol. 21, No. 2, pp. 277 28, 277-288.

Olsson, et al. 2007. Enhancing the fit through adaptive co-management: creating and maintaining bridging functions for matching scales in the Kristianstads Vattenrike Biosphere Reserve Sweden. Ecology and Society 12(1).

Ostrom, E. 1990. Governing the commons. Cambridge: Cambridge University
Press.

Ostrom, E. 2005. Understanding institutional diversity. Princeton, New Jersey, USA: Princeton University Press.

Pitcher \& Lam. 2010. Fishful Thinking Rhetoric, Reality, and the Sea Before Us. Ecology and Society, Vol. 15, No. 2.

Plummer et al. 2017. Diagnosing adaptive comanagement across multiple cases. Ecology and Society, Vol. 22, No. 3.

Pomeroy et al. 2016. Driversandimpactsof fisheries scarcity,competition, and conflict on maritime security. Marine Policy 67, 94-104.

Pomeroy R., Berkes, F. 1997. Two to tango: the role of government in fisheries co-management. Marine Policy 21(5), 465-480. 